\title{
THE USE OF COMMUNICATION MEDIA IN THE TEACHING AND LEARNING PROCESS AT UNIVERSITIES IN ACEH DURING THE COVID-I 9 PANDEMIC
}

\author{
Reni Juliani',Putri maulina', Rena Juliana ${ }^{2}$ \\ I Universitas Teuku Umar \\ 2 STAIN Teungku Dirundeng Meulaboh
}

\begin{abstract}
Covid 19 cases in Indonesia have been published since early March 2020. These cases have continued to increase significantly, spreading to almost all provinces in Indonesia including Aceh Province. In fact, Aceh province is the province with the highest increase in coronavirus deaths in mid-October. As conditions deteriorate, the government continues to implement policy reforms to suppress the spread of Covid19, including policies in the education world using online methods. Online learning is an educational innovation that uses elements of information technology as a means of support. This study aims to answer the question, how do online communication and learning at universities in Aceh during the Covid-19 pandemic? The theory used in this research is the theory of technological determinism. This research uses qualitative methods with descriptive analytical presentation. The research showed that Aceh universities used many online learning models such as the Zoom application, Google Classroom, WhatsApp and others. This is related to the interest of the application users. Online learning guidelines also have advantages and disadvantages with students and lecturers studying at universities in Aceh.
\end{abstract}

\author{
Keywords \\ (Media, Communication, \\ Teaching and Learning, Aceh, \\ Covid-19 Pandemic)
}

Correspondence Contact putrimaulina@utu.ac.id

\section{INTRODUCTION}

Corona virus disease 2019 (Covid-19) is still a serious problem worldwide. This virus was discovered in Wuhan City, China from the beginning in late December 2019 and has spread to almost all parts of the world. Its rapid spread hits anyone contaminated with deadly effects.

In Indonesia, the results of the Covid-19 case have been published since the beginning of March 2020 and have continued to grow significantly so far. Based on data from the Covid-19 Task Force on Dealing with Indonesia, Indonesia recorded that by September 30, 2020, a total of 283,000 cases were positive, 210,000 had been declared cured and 10,601 patients had died. WikuAdisasmito, spokesman for the Covid-19 Handling Task Force, said the Covid-19 Acceleration Task Force found that Aceh was the province with the highest increase in deaths from corona virus in the past week or October 12-18. This condition also puts Aceh at the forefront of the increase in Covid-19 deaths from priority provinces for treatment.The highest increase in the number of deaths was recorded in Aceh, an increase of 43.8 percent. The second highest number of deaths was occupied by South Sulawesi with a 42.9 percent increase. Then came North Sumatra by 34.8 percent and Central Java by 23 percent.In fifth place is South Kalimantan with a 9.1 percent increase in deaths and DKI Jakarta with a 6.7 percent increase in deaths (cnnindonesia, 2020). 
The Covid-19 pandemic has changed the way people live in social, economic, political and educational terms. The government continues to update guidelines to reduce the spread of Covid-19. New guidelines are also being applied in the educational world. Government advice to stay home and engage in activities from home during the pandemic must be followed to break the chain of spread of Covid-19. Therefore, changing the learning methods, which usually take place right in the classroom, is enough to learn from home or from what is known as online learning. This applies to all educational institutions including the lectures specified in Circular No. 4 of 2020 of the Minister of Education and Culture regarding the repeal of the national examination and education policy in the Covid-19 emergency period.

Professor at Hanover University of Applied Sciences and Senior Expert Services (SES), Prof. DR. GerhadFortwengel, said that the corona outbreak was indeed a great catalyst that spurred the world of education, for example promoting the increased use of information technology in distance learning. However, implementing the distance learning model presents major challenges. One of these is that the academic community is not yet accustomed to using a blended and fully online learning system (Ika, 2020).

Badriyah (Supriyatno, 2020) notes that in responding to cases and phenomena, as well as government policy, the world of education is naturally beginning to improve online learning for students as a form of human awareness who have to keep trying in the midst of adversity. Face-to-face communication patterns using the facilities of the age of globalization with the elearning method can be an alternative solution to learning problems. Several universities have also prepared Zoom meetings, namely video conferencing applications, which are used on all platforms, both Android, IOS, MAL, Windows and Google Classroom, with the hope that the online service system will continue to interact in real time. So far, in the millennium era, the knowledge of the students regarding online learning is indeed preferred, although some faculty and students are still doing assignments, but the opinions of some information technology experts are lessons that can be learned during the coronavirus outbreak. Educational guidelines restrict face-to-face learning and replace it with online learning to help prevent Covid-19 transmission.

In online learning, there is a learning model that uses a variety of applications such as WhatsApp, Google Classroom, Zoom, and others. The aim is to make the teaching and learning process more comfortable and understandable for teachers and students. Online learning is an educational innovation that uses elements of information technology as a means of support. The online learning system continues to provide support for teachers and students as to its application or use, as this online system is included in learning methods or learning facilities that also need to be clarified. This study aims to answer the question, how do the use of communication media in the teaching and learning process at universities in aceh during the covid19 pandemic.

\section{THEORETICAL STUDY}

\section{Online Learning}

Online learning is an educational innovation that uses elements of information technology as a means of support. According to Azhar (Pohan, 2020: 1), online learning is anything that can bring information and knowledge to the interactions between education and students. The tools used in learning are based on the subject matter and the characteristics of the students and are considered to be very effective at conveying information so that students can understand well. 
Clark \& Mayer (Yuliani et al., 2020: 3) stated that e-learning has characteristics including:

1. Have content that is relevant to the learning objectives;

2. Use teaching methods such as presenting examples and exercises to improve learning;

3. Use media elements such as words and images to convey learning materials;

4. Enables direct teacher-centered learning (synchronous e-learning) or for independent learning (asynchronous e-learning);

5. Build understanding and skills related to learning objectives, either individually or to improve learning performance in a group.

\section{Communication}

In Indonesia, the history of communication as a science is relatively new. So far, studies of communication have been limited to how a message was spread. For this reason, the faculty or study program that organizes this study is called the Publications Faculty or Public Relations Department, for example at the University of Indonesia (UI), the University of Padjajaran (UNPAD), the University of Gadjahmada (UGM)) and the University of Hasanuddin (UNHAS). Communication usually relates to journalism, public relations and information. This name change from publication studies to communication science has resulted in a change in the determination of the study problem (subject matter). In publication studies, many adopt terms and theories that originated in Germany, while many, after having become a communication science, adopt terms, theories and methods developed in the USA (Panuju, 2018: 17).

The definition of communication according to Lauwrence D. Kincaid (1987) in (Cangara, 2014: 36 ) is defined as a process in which two or more people exchange information with each other, which in turn leads to a deep mutual understanding. In the meantime, Shannon and Weaver (Wiryanto, 2004: 7) state that communication is a form of human interaction that influences one another, whether on purpose or not, and is not limited to forms of verbal communication, but also to facial expressions, painting, art and technology. The elements in communication that are interdependent, namely: source, message, channel, receiver, effect (Mulyana, 2009: 69).

Communication is required in the order of human life. In any situation, including during the Covid-19 pandemic like now, communication cannot be stopped just because of the situation. So today's communication culture is more about communicating through the media to make communication easier and to adhere to government recommendations for maintaining distance. Media is a tool or means of conveying messages from communicators to the public. There are several psychology experts who believe that in human communication, the five human senses such as the eyes and ears are the dominant communication media. The messages received by the five senses are then processed in the human mind to control and determine their attitudes towards something before being expressed in action (Cangara, 2011: 125).

\section{Previous Study}

Nadeak (2020: 1764) conducted a study regarding to the effectiveness of distance learning using social media such as Facebook, Instagram, and Youtube during the pandemic period of Covid-19. The results of the social media distance learning effectiveness test concluded that social media distance learning was only effective for theoretical subjects, while social media was less effective for practical courses and distance learning topics. 
The difference in this study compared to previous research is that this research is concerned with the use of applications such as Zoom, WhatsApp, and Google Meet, while previous research uses Facebook, Instagram, and Youtube. This study suggests the results that the use of these applications has not been effective for the teaching and learning process using the online learning system during the pandemic.

\section{Theory of Technological Determinism}

The theory used in this research is the theory of technological determinism. This theory was first proposed by Marshall McLuhan in his 1962 article the Guttenberg Galaxy: the Making of Typographic Man. The basic idea of this theory is that changes that occur in different types of communication also shape human existence itself (Nurudin, 2015: 185).

Technology shapes individuals in terms of how they think and behave in society, and this technology eventually leads people to move from one technological century to another. McLuhan believes that our culture is shaped by how we communicate. The theory of technological determinism consists of three phases (Nurudin, 2015: 185):

1. The discoveries in communication technology led to cultural changes.

2. Changes in the type of communication ultimately shape human life.

3. Communication technology delivers messages and shapes our own behavior.

\section{METHODOLOGY}

This study used a qualitative research method with a descriptive analysis presentation. Bagdan and Taylor (Moleong, 2013: 4) define qualitative methodology as a research process that generates descriptive data in the form of written or spoken words of people and observable behavior.

This research focused on the use of communication media in online learning models at universities during the Covid-19 pandemic in Aceh. The data source in this study was the topic from which the data was obtained (Arikunto, 2010: 107). According to Sugiyono (2012: 62), the source of qualitative research data in this study was the primary data source that was obtained directly from informants via Google form and participatory observation. Secondary data sources were obtained from literature studies or previous studies and graphical documents such as tables, notes, photos and other reading sources that were relevant to the research topic.

Data collection techniques in this study were observation and online interviews. Research informants are people who provide researchers or in-depth interviewers with information about themselves and others or an event or something else (Afrizal, 2016: 139). The sampling method in this study uses a "non probability" sampling method, namely "Purposive Sampling". The participants in this study amounted to 40 informants from different campus backgrounds and also different jobs in Aceh.

\section{RESULTS AND DISCUSSIONS}

Results

Online learning in Indonesia is not new. However, the scope is still limited. Typically, online learning models are only implemented for educational institutions in urban areas. The 
emergence of the Covid-19 outbreak is a new chapter in the world of education. This is felt by all students in the world, including in Indonesia, especially in the Aceh province.

The online learning model is still used in various educational institutions, especially universities. Different learning methods are used to help students stay productive from home. The online learning models used also vary, starting with using the Zoom application, Google Classroom, WhatsApp and others. This is related to the interest of the application user.

Based on the results of online interviews with around 40 informants from different campus backgrounds and also different jobs, it was found that the type of online learning media used frequently is the WhatsApp application. Of the 40 informants, 23 people reported using WhatsApp media, 15 people Google Classroom media, 1 person Google Classroom and WhatsApp, 1 person Zoom meetings.

However, online learning policy also has advantages and disadvantages for students and lecturers at universities in Aceh. There are many reasons for this, such as an unstable or no internet connection for certain areas, the unavailability of internet allotments and others.

The following is the answer from an interview with one of the informants starting with JS, who is a student at University of Teuku Umar, said:

"Understanding learning is difficult due to intermittent network constraints, not to mention disruption from home that disrupts learning activities and is also constrained by internet quotas that must always be there even when the economy is tough".

The same was conveyed by IDN, who is also a student at Teuku Umar University, said:

"I think this online method is less effective. Where lecturers and students only use electronic media. It is quite different from previously using the face-to-face method so for me online methods like this are less effective because we only know a small part of the material that is not as usual using face-to-face methods, which is where we can find out more area of the material".

Another answer was given by Johan, a student at the University of Teuku Umar, who stated:

"It takes longer to understand the material presented as it is explained or delivered in the form of written media. Hence, it takes time and time to understand this. Unlike face-to-face meetings, there are more interactions and explanations that students understand more quickly because of face-to-face communication. There are also barriers due to teachers being less effective in delivering material and the learning system is applied in online media."

Nawal, a student at the University of Syiah Kuala, added, "Instead of studying online, it is better to provide educational videos in an easy-to-understand language. So the students can repeat the material at any time."

Lia, a post graduate student at UIN Ar-Raniry, stated, "The advantage of online learning is that the teaching and learning process is easier because you can study at home. However, this method is less effective because that material is difficult to understand. In addition, there is sometimes a lack of communication with group members via WhatsApp and the difficulty of applying time discipline."

On the other hand, there were also those who responded with a positive statement from one of the lecturers at the University of Teuku Umar, Khalis: 
"Students can follow the latest technology and the negative side is the lack of network services for remote villages."

UmmiHabibah, one of the lecturers at STAIN TeungkuDirundengMeulaboh, said: "The resulting online learning method has a positive side: the material can be accessed by students anywhere, anytime, giving lectures while doing other activities, as well as avoiding the corona virus. However, these teaching learning activities are not as effective as face-to-face learning and cannot ensure that students participate in class as is normally the case in face-to-face teaching."

Unlike another STAIN TeungkuDirundengMeulaboh lecturer, who was also an informant in this study, but did not want to be named. He explained that "Online learning methods have a positive impact, namely that they can demand independence for students. Monitoring and assessment are digitally formatted, which makes it easier for lecturers, and time is felt to be more flexible. Achieving lecture goals is also not limited to the teaching hours set by the academics, but the disadvantage is that there is no direct communication."

Another lecturer at STAIN TeungkuDirundengMeulaboh also replied that "online learning is quite difficult to implement as both lecturers and students have limited ability to use technology."

\section{Discussions}

The world of education has changed since the Covid-19 pandemic. In-person learning between teachers and students is being replaced by online learning, in which distance learning between teachers and students is carried out via the Internet network. Indonesia has more than 4,000 state and private universities, with 98 percent of them applying distance learning during the health crisis, according to the Education and Culture Ministry.The government has also allocated 7.2 trillion Rupiah (US $\$ 532$ million) in mobile phone credit and data plans to support distance learning for the nation's 8 million university students and 250,000 lecturers, as well as primary and secondary school students. The ministry has registered 78 percent of the university students' mobile phone numbers and 85 percent of the lecturers' numbers on their system. ParistiyantiNurwardani, the secretary of the Higher Education Directorate General, said they would disburse the subsidized 35 gigabytes of monthly internet data per student late this month (Cahya, 2020).

New problems arose. The availability of internet quotas does not necessarily solve various problems of online learning. The Internet network sometimes poses its own problems for lecturer and students who live in areas with limited Internet networks. The minimal internet network becomes an obstacle to holding online lectures. This is illustrated in Picture 1 and Picture 2. 


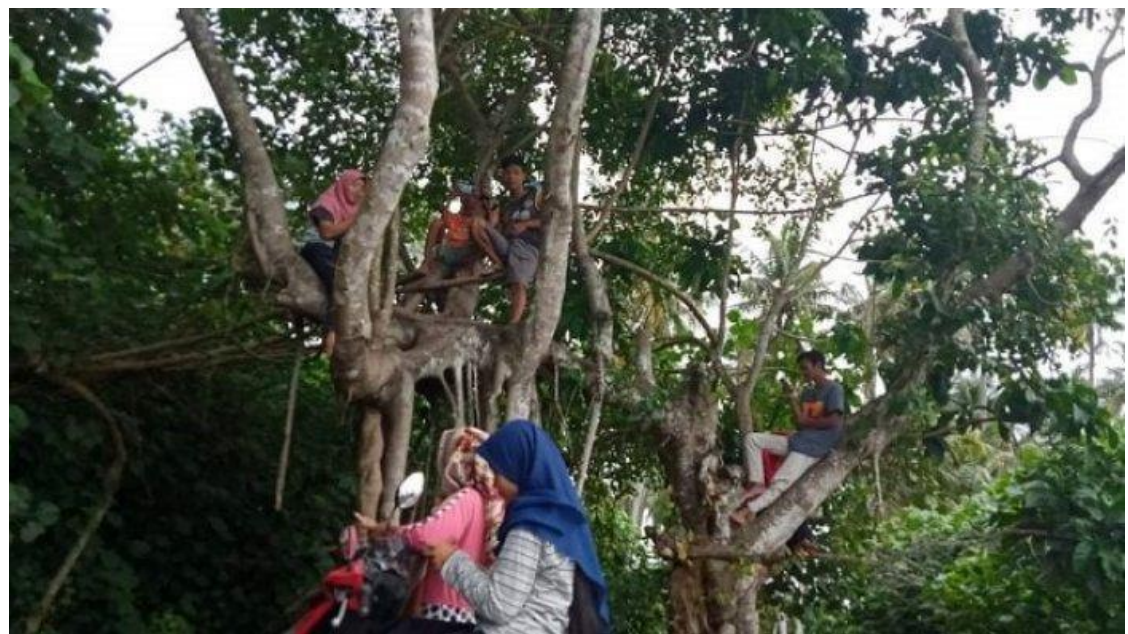

Picture 1. Simeulue students are taking an online lecture by climbing a tree because of the difficulty of getting an internet network, this photo was recently taken in Alafan District.

(Muliyasno, 2020)

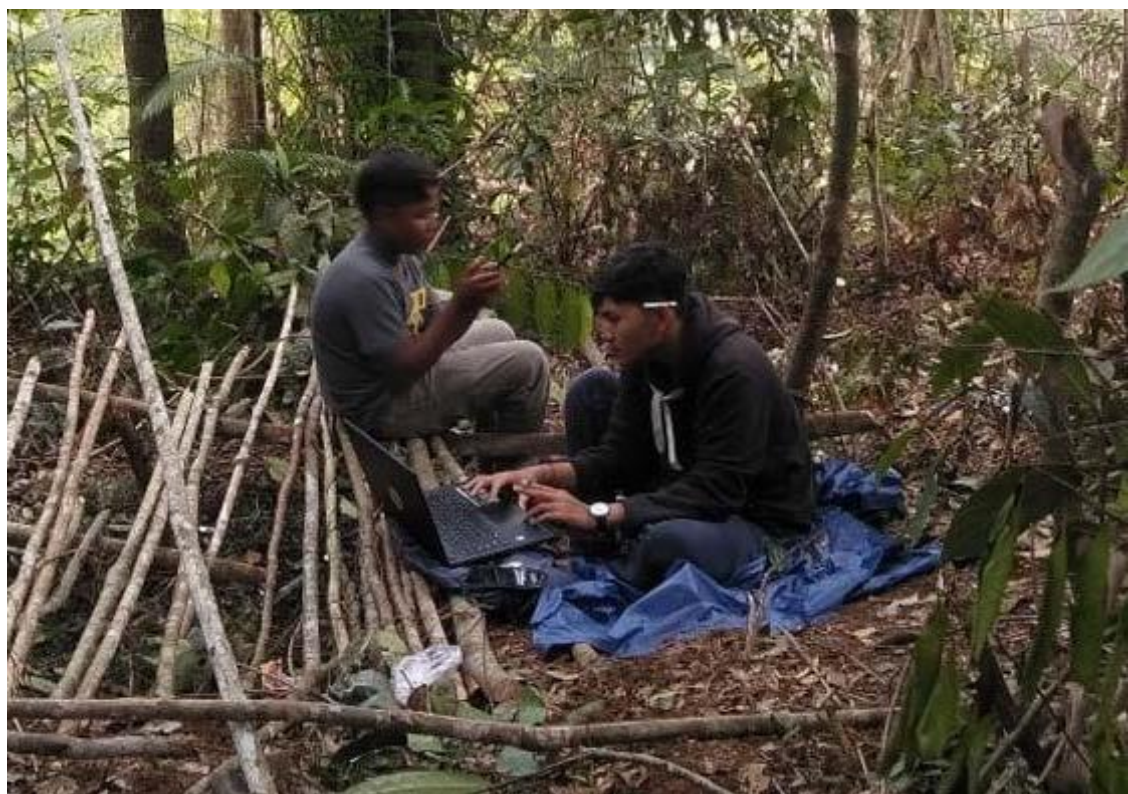

Picture 2. Students climb the Mount Singgah Mata area in the BeutongAteuhBanggalang District, Nagan Raya, Aceh to search for internet signals for online lectures. Because regular lectures have been eliminated due to the coronavirus or Covid-19. (Rizwan, 2020)

Online learning has a positive and negative side that go hand in hand. As a result, how effective online learning is during this Covid-19 pandemic. The meaning of the word effective according to KBBI is that there is an effect, consequence, influence and or results or is effective. Therefore, the degree of effectiveness can be described as relative, depending on the particular components that support or participate in this online learning process, so that it is hoped that this learning will bring the best results despite the existing limitations. Students are expected to be independent and learn more actively, relying not only on the material given but on other sources as well. Lecturers and faculties/ universities should adapt the curriculum to the current situation so that online lectures can continue to be carried out and are not too timeconsuming. It also requires a learning model that is attractive, active, and acceptable to all 
types of students. The government is also trying best to support continuity of learning during the Covid-19 pandemic by providing internet quota subsidies for students, teachers, students and faculty members every month. In the long run, online learning can limit the field activities or internship that support the course, requiring innovation for blended learning as conditions improve and health protocols to be implemented on campus (Putri, 2020).

Since the Covid-19 pandemic, online learning methods have been the best alternative step to date for delivering lectures on campus. Of course, the online learning method also has advantages and disadvantages, including (Yassin, 2020):

1. Advantages of online learning

a. Save transport costs

Students who normally have to come directly to campus to attend lectures but no longer need to come to campus will automatically no longer have the costs that would normally be incurred for buying gasoline/ public transportation.

b. Save time and energy

Of course, the time spent on in-person lectures is longer than on online lectures, as the change of hours between courses and other courses is sometimes very delayed and therefore has to be waited for on campus.

c. Feel more relaxed and avoid noise

Using online lectures feels calmer and more relaxed and can be done at home, in your room, in a coffee shop, or anywhere, as long as there is adequate internet access and equipment.

2. Disadvantages of online learning

a. Compulsory internet access

Online lectures certainly require internet access with various available mediators such as laptops, iPads, smartphones, etc.

b. Submission and acceptance of material is not optimal

The teaching and learning process is not always easy for students to understand, especially when the process is only online. Of course, the concentration of the students and the acceptance of the presented material is no better than in personal lectures.

c. Limitations in practice and frequently asked questions

For theoretical courses it will not be too problematic to be faced with online lectures, but for hands-on courses, online lectures are not a solution, and the impact of this situation, the students' knowledge and understanding of the course material is not optimal.

\section{CONCLUSION}

The online learning model is still used in various educational institutions, especially universities in Aceh. Different learning methods are used to help students stay productive from home. Higher education institutions in Aceh have many online learning models using the Zoom application, Google Classroom, WhatsApp, and others. It is related to the interest of the application user. Online learning guidelines also have advantages and disadvantages with students and lecturers studying at colleges in Aceh. There are many reasons for this, such as: an unstable internet connection that doesn't even exist in certain areas, the unavailability of internet allotments and others. However, through online learning, they are better trained technologically and used to using Internet-based media. 


\section{REFERENCES}

Afrizal. (2016). Metode Penelitian Kualitatif: Sebuah Upaya Mendukung. Penggunaan Kualitatif dalam Berbagai Disiplin Ilmu. Jakarta: Rajawali Press.

Arikunto, Suharsimi. (2010). Prosedur Penelitian Suatu pendekatan Praktek. Jakarta: Rineka Cipta.

Cahya, Gemma Holliani. (2020). Generation Zoom: Freshmen forced to start university life in solitude. https://www.thejakartapost.com/news/2020/09/24/generation-zoomfreshmen-forced-to-start-university-life-in-solitude.html

Cangara, Hafied. (2011). Pengantar Ilmu Komunikasi. Jakarta: Raja Grafido Persada.

. (2014). Pengantar Ilmu Komunikasi. Jakarta: RajaGrafindo Persada.

Cnnindonesia. (2020). Satgas Catat Aceh Jadi Provinsi Kematian Covid-19 Tertinggi. https://www.cnnindonesia.com/nasional/20201022190938-20-561723/satgascatat-aceh-jadi-provinsi-kematian-covid-19-tertinggi.

Ika. (2020). Membedah Tantangan Pembelajaran Daring di Tengah Pandemi Covid-19. https://ugm.ac.id/id/berita/19552-membedah-tantangan-pembelajaran-daring-ditengah-pandemi-covid-19

Moleong, Lexy J. (2013). Metodologi Penelitian Kualitatif. Bandung: Remaja Rosdakarya.

Muliyasno, Sari. (2020). Demi Kuliah Obline Mahasiswa di Simeulue Harus Panjat Pohon untuk Dapat Sinyal. https://aceh.tribunnews.com/2020/10/01/demi-kuliah-onlinemahasiswa-di-simeulue-harus-panjat-pohon-untuk-dapat-sinyal.

Mulyana, Deddy. (2009). Ilmu Komunikasi: Suatu Pengantar. Bandung: Remaja Rosdakaraya.Nurudin. 2015. Pengantar Komunikasi Massa. Jakarta: Rajawali Pers.

Nadeak, Bernadetha. (2020). The Effectiveness of Distance Learning Using Social Media during the Pandemic Period of COVID-19: A Case in Universitas Kristen Indonesia. International Journal of Advanced Science and Technology, 29(7), 1764-1772.

Panuju, Redi. (2018). Pengantar Studi (Ilmu) Komunikasi: Komunikasi Sebagai Kegiatan Komunikasi Sebagai Ilmu. Jakarta: Kencana.

Pohan, Albert Efendi. (2020). Konsep Pembelajaran Daring Berbasis Pendekatan Ilmiah. Purwodadi-Grobogan: Sarnu Untung.

Putri, Cindy Ochtavia Yolanda. (2020). Pembelajaran Daring Efektif Gak Sih Buat Mahasiswa. https://egsa.geo.ugm.ac.id/2020/10/14/pembelajaran-daring-efektif-gak-sih-buatmahasiswa/

Rizwan. (2020). Kisah Mahasiswa di Pedalaman Aceh Kuliah Daring Naik Gunung Terjal untuk Cari Sinyal Internet. https://aceh.tribunnews.com/2020/04/06/kisah-mahasiswa-dipedalaman-aceh-kuliah-daring-naik-gunung-terjal-untuk-cari-sinyalinternet?page=all

Sugiyono. (2012). Metode Penelitian Pendidikan. Bandung: Alfabeta. 
Juliani, Reni. Dkk. The Use of Communication Media In The Teaching And Learning Process At Universities In Aceh During The Covid-19 Pandemic.

Supriyatno, Helmi. (2020). Pembelajaran Daring di Tengah Pandemi Covid-19. https://www.harianbhirawa.co.id/pembelajaran-daring-di-tengah-pandemi-covid$\underline{19 /}$

Wiryanto. (2004). Pengantar Ilmu Komunikasi. Jakarta: Grasindo.

Yassin, Beni Adri. (2020). Kuliah Online Daring. https://pustaka.unand.ac.id/component/k2/item/231-kuliah-online-daring

Yuliani, Meda, etc. (2020). Pembelajaran Daring untuk Pendidikan: Teori dan Penerapan. Medan: Yayasan Kita Menulis. 